\title{
Elucidation of the Roles of Blackcurrant reversion virus and Phytoplasma in the Etiology of Full Blossom Disease in Currants
}

\author{
Josef Špak, Darina Kubelková, Jaroslava Přibylová, Vlastimila Špaková, and Karel Petrzik, Biology Centre v.v.i., \\ Institute of Plant Molecular Biology, Academy of Sciences, Branišovská 31, 37005 České Budějovice, Czech Republic
}

\begin{abstract}
Špak, J., Kubelková, D., Přibylová, J., Špaková, V., and Petrzik, K. 2009. Elucidation of the roles of Blackcurrant reversion virus and phytoplasma in the etiology of full blossom disease in currants. Plant Dis. 93:832-838.

To determine the roles of phytoplasmas and Blackcurrant reversion virus (BRV) in the etiology of full blossom disease (FBD), we conducted graft and dodder transmission experiments. Scions from FBD-affected Ribes rubrum were grafted onto red currants, white currants, and black currants. Red and white cultivars revealed symptoms of FBD, whereas blackcurrant displayed symptoms of BRV. No differences in symptoms were observed between plants infected with BRV only and those infected with BRV and phytoplasma. Aster yellows phytoplasma subgroup 16SrI-C was transferred from FBD-infected red currants to periwinkle, where symptoms of green and yellow petal were observed. Back-transmission of phytoplasma to currant seedlings of red and black currant was not successful. Scions of periwinkle infected with aster yellows phytoplasmas of subgroup 16SrI-C and 16SrI-B, which were bottle-, bark-, and approach-grafted onto seedlings of red and black currant, resulted in positive but symptomless transmission of phytoplasma to red currant. We conclude that FBD symptoms are induced by BRV rather than by phytoplasma, which was originally described as the causal agent of FBD.
\end{abstract}

The full blossom disease (FBD) of red currant 'Houghton Castle' was first described in Bojnice, in the Slovak part of former Czechoslovakia (23). A possible association of this disease with phytoplasma infection was indicated (25) by the observation of pleomorphic bodies in the phloem of symptomatic racemes by transmission electron microscopy. Graft transmission of FBD in red currant has also been demonstrated (24).

Typical symptoms of FBD are an elongated style, the absence of stamens, and superior ovaries. Petals and sepals change color and may enlarge, multiply, and become leaf-like. Two characteristic features of the disease are the persistence of sterile flowers and production of malformed fruit with extruding seeds (32).

Full blossom is an economically important disease in Czechoslovakia (26). It has been found in red currant cultivars Houghton Castle, Jonkheer van Tets, Erstling aus Vierlanden, and several unnamed cultivars in several locations. Diseased bushes are reduced in size and produce sparse crops of small berries (26). Reductions in yield can reach $70 \%$.

Corresponding author: Josef Špak

E-mail: spak@umbr.cas.cz

* The $\boldsymbol{e}$-Xtra logo stands for "electronic extra" and indicates that the figures are in color online and that two additional figures are available online.

Accepted for publication 7 May 2009.

doi:10.1094/PDIS-93-8-0832

(c) 2009 The American Phytopathological Society
Since 1998 in the Czech Republic, multiple cultivars of red and white currants with FBD symptoms as described by Rakús (23) have been observed in many plantations (29). In Poland, FBD was recorded in red currant cultivar Jonkheer van Tets and white currant cultivar Blanka (14).

Phytoplasmas (aster yellows group, subgroup 16SrI-B [AY-IB] and subgroup 16SrI$\mathrm{C}$ [AY-IC], and apple proliferation group, subgroup $16 \mathrm{SrX}-\mathrm{A}$ ) were found to be associated with FBD in red and white currants based on polymerase chain reaction (PCR), restriction fragment length polymorphism (RFLP), sequence analysis, and electron microscopy (15). We later detected Blackcurrant reversion virus (BRV; Nepovirus, Comoviridae) in red and white currants with symptoms of FBD (21). Economically, BRV is the most important virus infecting Ribes sp. (31). Our previous study of symptomatic bushes naturally affected with FBD demonstrated that although phytoplasmas were present in some bushes (15), BRV was detected by reverse transcription (RT)-PCR in all bushes $(100 \%)$.

To elucidate the roles of BRV and phytoplasma in FBD, we conducted graft experiments and focused on phytoplasma transmission in currants by dodder and grafting.

\section{MATERIALS AND METHODS}

Graft transmission of FBD to currant cultivars. In 1999, seedlings of red currants (cvs. Vitan, Rondom, and Jonkheer van Tets), white currant (cv. Blanka), and black currants (cvs. Öjebyn and Viola) were barkgrafted using 3-bud scions from red currants
Vitan and Heinemann and the white currant Blanka, which exhibited symptoms of FBD and originated from a plantation in Lhenice, Czech Republic. Seedlings of currant cultivars were purchased from the Research and Breeding Station at Velké Losiny, North Moravia. Forty to 60 seedlings of each cultivar were grafted (Table 1). Grafting was conducted at the end of August, which is the optimal time for grafting. Smooth and straight cuts were carefully executed on both the scion and rootstock, such that the phloem fitted together to facilitate phytoplasma transmission. The graft was firmly wrapped with self-adhesive tape and covered with a plastic bag for 3 months to ensure an optimal microclimate for successful survival of scions. Symptoms were observed from 2000 to 2008 during bloom (April and May), at which time malformed flowers with abnormal shapes and colors were clearly visible (Table 2).

As described below, plants were repeatedly tested by RT-PCR for the presence of BRV in 2004, 2005, 2006, and 2008, and by PCR for the presence of phytoplasma in 2003, 2005, and 2008. All PCR products obtained from phytoplasma detection experiments were sequenced to identify the phytoplasma species and eliminate false positive results. The plants were maintained in an insect-proof net-house at the Biology Centre, Institute of Plant Molecular Biology in České Budějovice. Prior to the grafting experiments, all plants were tested for Apple mosaic virus (ApMV), Arabis mosaic virus (ArMV), Tomato ringspot virus (ToRSV), Cherry leaf roll virus (CLRV), Alfalfa mosaic virus (AMV), Tobacco streak virus (TSV), Strawberry latent ringspot virus (SLRSV), Tomato black ring virus (TBRV), Raspberry ringspot virus (RpRSV), Raspberry bushy dwarf virus (RBDV), and Cucumber mosaic virus (CMV) using ELISA kits from Bioreba AG and Loewe Biochemica according to the manufacturer's protocols.

Graft transmission of FBD to seedlings of Jonkheer van Tets and Baldwin currants. Three-year-old seedlings of Jonkheer van Tets and Baldwin (Table 1, lower part) were bark-grafted using scions from cultivars Jonkheer van Tets, Vitan, Blanka, and Rožmitál exhibiting symptoms of FBD (Table 3). Test plants were raised from seed and cultivated in an insect-free greenhouse to avoid any possibility of contamination by BRV or phytoplasma. All transmission experiments were regularly treated by acari- 
cides, and no mite-induced galls were observed on shrubs. Symptoms were observed in 2004 to 2008 , and the plants were repeatedly tested by RT-PCR for BRV in 2005 and 2008 and by PCR for phytoplasma in 2005, 2006, and 2008 using the methods described below.
Dodder transmission of phytoplasmas from currants to periwinkle and their back-transmission to red and black currants. Plants infected with BRV and phytoplasma, as indicated by RT-PCR, PCR, and sequencing, were selected for the experiment (Table 4). A red currant plant of unknown cultivar from a location in Rožmitál (hereafter Rožmitál), the red currants Vitan K2, K3, K7, and K8, and the white currant Blanka K5 were naturally infected in the field, and all exhibited FBD symptoms. Black currant Viola 5 and Viola 52 originated from graft transmission ex-

Table 1. Graft transmission of full blossom disease to currants

\begin{tabular}{|c|c|c|c|c|c|c|c|c|}
\hline \multirow[b]{2}{*}{ Currant } & \multirow[b]{2}{*}{ Cultivar } & \multirow{2}{*}{$\begin{array}{l}\text { No. of grafted } \\
\text { plants }\end{array}$} & \multicolumn{2}{|c|}{ Plants with symptoms } & \multicolumn{2}{|c|}{$\mathbf{B R V} \mathbf{a}^{\mathbf{a}}$} & \multicolumn{2}{|c|}{ Phytoplasmab $^{b}$} \\
\hline & & & No. & $(\%)$ & No. & $(\%)$ & No. & $(\%)$ \\
\hline \multirow[t]{3}{*}{ Red } & Rondom & 53 & 1 & $2 \%$ & 0 & $0 \%$ & 0 & $0 \%$ \\
\hline & Jonkheer van Tets & 58 & 7 & $12 \%$ & 7 & $12 \%$ & 1 & $2 \%$ \\
\hline & Vitan & 56 & 13 & $23 \%$ & 14 & $25 \%$ & 0 & $0 \%$ \\
\hline White & Blanka & 55 & 13 & $24 \%$ & 13 & $24 \%$ & 1 & $2 \%$ \\
\hline \multirow[t]{2}{*}{ Black } & Viola & 37 & 4 & $11 \%$ & 4 & $11 \%$ & 2 & $5 \%$ \\
\hline & Öjebyn & 60 & 0 & $0 \%$ & 2 & $3 \%$ & 0 & $0 \%$ \\
\hline \multicolumn{9}{|l|}{ Seedlings } \\
\hline Red & Jonkheer van Tets & 15 & 5 & $33 \%$ & 15 & $100 \%$ & 1 & $7 \%$ \\
\hline Black & Baldwin & 41 & 0 & $0 \%$ & 2 & $5 \%$ & 1 & $2 \%$ \\
\hline
\end{tabular}

${ }^{a}$ BRV, Blackcurrant reversion virus. Tested by reverse transcription-polymerase chain reaction.

$\mathrm{b}$ Tested by polymerase chain reaction.

Table 2. Symptoms and the presence of Blackcurrant reversion virus and phytoplasma in currant cultivars after graft transmission of full blossom disease ${ }^{\mathrm{a}}$

\begin{tabular}{|c|c|c|c|c|c|c|c|c|c|c|c|c|}
\hline \multirow[b]{2}{*}{ Cultivar } & \multirow[b]{2}{*}{ Plant } & \multirow[b]{2}{*}{ Scion } & \multicolumn{8}{|c|}{ Symptoms $^{b}$} & \multicolumn{2}{|c|}{$\mathbf{P C R}^{\mathrm{c}}$} \\
\hline & & & 2001 & 2002 & 2003 & 2004 & 2005 & 2006 & 2007 & 2008 & BRV & Phytoplasma \\
\hline Rondom & 28 & Vitan & FBD & $\mathrm{HF}$ & $\mathrm{HF}$ & $\mathrm{HF}$ & $\mathrm{HF}$ & $\mathrm{HF}$ & $\mathrm{HF}$ & $\mathrm{HF}$ & $\mathrm{N}$ & $\mathrm{N}$ \\
\hline \multirow[t]{7}{*}{ Jonkheer } & 2 & Vitan & FBD & FBD & $\mathrm{HF}$ & $\mathrm{HF}$ & FBD & FBD & FBD & FBD & $\mathrm{P}$ & $\mathrm{N}$ \\
\hline & 10 & Blanka & FBD & $\mathrm{HF}$ & $\mathrm{HF}$ & $\mathrm{HF}$ & FBD & $\mathrm{HF}$ & FBD & $\mathrm{HF}$ & $\mathrm{P}$ & AY-IC \\
\hline & 39 & Vitan & FBD & FBD & FBD & $\mathrm{D}$ & D & $\mathrm{D}$ & D & $\mathrm{D}$ & $\mathrm{P}$ & $\mathrm{N}$ \\
\hline & 68 & Vitan & $\mathrm{HF}$ & $\mathrm{HF}$ & $\mathrm{HF}$ & $\mathrm{HF}$ & $\mathrm{HF}$ & FBD & FBD & $\mathrm{HF}$ & $\mathrm{P}$ & $\mathrm{N}$ \\
\hline & 71 & Vitan & $\mathrm{HF}$ & FBD & FBD & FBD & FBD & FBD & FBD & FBD & $\mathrm{P}$ & $\mathrm{N}$ \\
\hline & 77 & Vitan & $\mathrm{HF}$ & FBD & FBD & FBD & FBD & FBD & FBD & FBD & $\mathrm{P}$ & $\mathrm{N}$ \\
\hline & 83 & Vitan & $\mathrm{HF}$ & FBD & FBD & $\mathrm{HF}$ & FBD & FBD & FBD & FBD & $\mathrm{P}$ & $\mathrm{N}$ \\
\hline \multirow[t]{14}{*}{ Vitan } & 7 & Vitan & FBD & FBD & $\mathrm{HF}$ & $\mathrm{HF}$ & FBD & $\mathrm{HF}$ & $\mathrm{HF}$ & $\mathrm{HF}$ & $\mathrm{P}$ & $\mathrm{N}$ \\
\hline & 15 & Vitan & $\mathrm{HF}$ & FBD & $\mathrm{HF}$ & FBD & $\mathrm{HF}$ & $\mathrm{HF}$ & $\mathrm{HF}$ & $\mathrm{HF}$ & $\mathrm{P}$ & $\mathrm{N}$ \\
\hline & 44 & Vitan & FBD & FBD & $\mathrm{HF}$ & $\mathrm{HF}$ & $\mathrm{HF}$ & $\mathrm{HF}$ & $\mathrm{HF}$ & $\mathrm{HF}$ & $\mathrm{P}$ & $\mathrm{N}$ \\
\hline & 54 & Blanka & FBD & $\mathrm{HF}$ & $\mathrm{HF}$ & $\mathrm{HF}$ & $\mathrm{HF}$ & $\mathrm{HF}$ & $\mathrm{HF}$ & $\mathrm{HF}$ & $\mathrm{P}$ & $\mathrm{N}$ \\
\hline & 72 & Blanka & $\mathrm{HF}$ & $\mathrm{HF}$ & $\mathrm{HF}$ & $\mathrm{HF}$ & $\mathrm{HF}$ & $\mathrm{HF}$ & $\mathrm{HF}$ & $\mathrm{HF}$ & $\mathrm{P}$ & $\mathrm{N}$ \\
\hline & 74 & Blanka & FBD & FBD & FBD & $\mathrm{HF}$ & FBD & FBD & FBD & $\mathrm{HF}$ & $\mathrm{P}$ & $\mathrm{N}$ \\
\hline & 75 & Blanka & $\mathrm{HF}$ & FBD & FBD & $\mathrm{HF}$ & FBD & FBD & FBD & $\mathrm{HF}$ & $\mathrm{P}$ & $\mathrm{N}$ \\
\hline & 81 & Vitan & FBD & $\mathrm{HF}$ & $\mathrm{HF}$ & $\mathrm{HF}$ & FBD & $\mathrm{HF}$ & $\mathrm{HF}$ & $\mathrm{HF}$ & $\mathrm{P}$ & $\mathrm{N}$ \\
\hline & 87 & Vitan & $\mathrm{HF}$ & FBD & $\mathrm{HF}$ & $\mathrm{HF}$ & FBD & $\mathrm{HF}$ & FBD & $\mathrm{HF}$ & $\mathrm{P}$ & $\mathrm{N}$ \\
\hline & 90 & Vitan & $\mathrm{HF}$ & FBD & FBD & FBD & FBD & FBD & FBD & FBD & $\mathrm{P}$ & $\mathrm{N}$ \\
\hline & 91 & Vitan & FBD & $\mathrm{HF}$ & $\mathrm{HF}$ & $\mathrm{HF}$ & FBD & $\mathrm{HF}$ & $\mathrm{HF}$ & FBD & $\mathrm{P}$ & $\mathrm{N}$ \\
\hline & 92 & Heinemann & FBD & FBD & $\mathrm{HF}$ & $\mathrm{HF}$ & FBD & FBD & $\mathrm{HF}$ & $\mathrm{HF}$ & $\mathrm{P}$ & $\mathrm{N}$ \\
\hline & 95 & Vitan & FBD & FBD & $\mathrm{HF}$ & $\mathrm{HF}$ & FBD & FBD & $\mathrm{HF}$ & $\mathrm{HF}$ & $\mathrm{P}$ & $\mathrm{N}$ \\
\hline & 102 & Vitan & FBD & FBD & $\mathrm{HF}$ & $\mathrm{HF}$ & $\mathrm{HF}$ & FBD & FBD & $\mathrm{HF}$ & $\mathrm{P}$ & $\mathrm{N}$ \\
\hline \multirow[t]{13}{*}{ Blanka } & 18 & Vitan & $\mathrm{HF}$ & FBD & FBD & FBD & FBD & FBD & FBD & FBD & $\mathrm{P}$ & AY-IC \\
\hline & 27 & Vitan & $\mathrm{HF}$ & $\mathrm{HF}$ & $\mathrm{HF}$ & $\mathrm{HF}$ & FBD & $\mathrm{HF}$ & FBD & $\mathrm{HF}$ & $\mathrm{P}$ & $\mathrm{N}$ \\
\hline & 28 & Vitan & $\mathrm{HF}$ & FBD & $\mathrm{HF}$ & $\mathrm{HF}$ & $\mathrm{HF}$ & $\mathrm{HF}$ & $\mathrm{HF}$ & FBD & $\mathrm{P}$ & $\mathrm{N}$ \\
\hline & 29 & Vitan & $\mathrm{HF}$ & FBD & FBD & FBD & FBD & FBD & FBD & FBD & $\mathrm{P}$ & $\mathrm{N}$ \\
\hline & 33 & Vitan & $\mathrm{HF}$ & FBD & FBD & FBD & FBD & FBD & $\mathrm{HF}$ & $\mathrm{HF}$ & $\mathrm{P}$ & $\mathrm{N}$ \\
\hline & 41 & Vitan & $\mathrm{HF}$ & FBD & FBD & FBD & FBD & FBD & FBD & FBD & $\mathrm{P}$ & $\mathrm{N}$ \\
\hline & 42 & Vitan & $\mathrm{HF}$ & FBD & $\mathrm{HF}$ & $\mathrm{HF}$ & FBD & FBD & FBD & FBD & $\mathrm{P}$ & $\mathrm{N}$ \\
\hline & 43 & Vitan & FBD & FBD & FBD & FBD & FBD & FBD & FBD & FBD & $\mathrm{P}$ & $\mathrm{N}$ \\
\hline & 46 & Vitan & $\mathrm{HF}$ & FBD & FBD & FBD & FBD & FBD & FBD & FBD & $\mathrm{P}$ & $\mathrm{N}$ \\
\hline & 52 & Vitan & $\mathrm{HF}$ & FBD & FBD & FBD & FBD & FBD & FBD & $\mathrm{HF}$ & $\mathrm{P}$ & $\mathrm{N}$ \\
\hline & 53 & Vitan & $\mathrm{HF}$ & FBD & $\mathrm{HF}$ & $\mathrm{HF}$ & $\mathrm{HF}$ & FBD & FBD & FBD & $\mathrm{P}$ & $\mathrm{N}$ \\
\hline & 70 & Heinemann & $\mathrm{HF}$ & $\mathrm{HF}$ & FBD & FBD & FBD & FBD & FBD & FBD & $\mathrm{P}$ & $\mathrm{N}$ \\
\hline & 77 & Vitan & $\mathrm{HF}$ & FBD & FBD & FBD & FBD & FBD & FBD & FBD & $\mathrm{P}$ & $\mathrm{N}$ \\
\hline \multirow[t]{4}{*}{ Viola } & 5 & Vitan & $\mathrm{HF}$ & BCRD & BCRD & BCRD & BCRD & BCRD & BCRD & BCRD & Ps & AY-IB \\
\hline & 52 & Vitan & $\mathrm{HF}$ & BCRD & BCRD & BCRD & BCRD & BCRD & BCRD & BCRD & Ps & AY-IB \\
\hline & 55 & Vitan & $\mathrm{HF}$ & BCRD & BCRD & BCRD & BCRD & BCRD & BCRD & BCRD & $\mathrm{P}$ & $\mathrm{N}$ \\
\hline & 100 & Vitan & $\mathrm{HF}$ & $\mathrm{HF}$ & $\mathrm{HF}$ & HF & BCRD & BCRD & BCRD & BCRD & Ps & $\mathrm{N}$ \\
\hline \multirow[t]{2}{*}{ Öjebyn } & 14 & Blanka & $\mathrm{HF}$ & $\mathrm{HF}$ & $\mathrm{HF}$ & $\mathrm{HF}$ & $\mathrm{HF}$ & $\mathrm{HF}$ & $\mathrm{HF}$ & $\mathrm{HF}$ & Ps & $\mathrm{N}$ \\
\hline & 88 & Blanka & $\mathrm{HF}$ & $\mathrm{HF}$ & $\mathrm{HF}$ & $\mathrm{HF}$ & $\mathrm{HF}$ & $\mathrm{HF}$ & $\mathrm{HF}$ & $\mathrm{HF}$ & $\mathrm{P}$ & $\mathrm{N}$ \\
\hline
\end{tabular}

a Grafting was done in 1999.

b FBD, full blossom disease; HF, healthy flowers; D, plant died; BCRD, blackcurrant reversion disease.

c PCR, polymerase chain reaction; BRV, Blackcurrant reversion virus; N, negative; P, positive; AY-IC, aster yellows phytoplasma (subgroup 16SrI-C); Ps, positive, sequenced; AY-IB, aster yellows phytoplasma (subgroup 16SrI-B). 
periments (Table 2) and exhibited symptoms of the R-form of blackcurrant reversion disease (BCRD).

Dodder raised from seed were grown on the currant plants and bridged to healthy periwinkle plants for 3 months. The periwinkle plants used in all experiments were raised from seed and tested negative by PCR for the presence of phytoplasma and BRV (RT-PCR) before the experiment. Symptoms were observed in periwinkle, and ultrathin sections were examined by transmission electron microscopy. After the transmission experiment, the periwinkle plants were again tested for the presence of phytoplasma and BRV, and the amplicons were sequenced using the methods described below. The plants were maintained in an insect-proof, airconditioned greenhouse.

In back-transmission experiments, dodder grown on periwinkle plants infected with AY-IC phytoplasma originating from red currant Rožmitál were bridged for 3 months to five seedlings of Jonkheer van Tets and two seedlings of Baldwin that tested negative by PCR and RT-PCR for the presence of phytoplasma and BRV, respectively, before the experiment. The currants were evaluated for symptoms in 2003 to 2008 and were tested repeatedly for the presence of phytoplasma in 2004, 2005, and 2006.

Dodder and graft transmission of phytoplasmas from periwinkle to Jonkheer van Tets and Baldwin indicator plants. Red currant Jonkheer van Tets and black currant Baldwin seedlings were bottle-, bark-, and approach-grafted using the scions of periwinkle plants infected with AY-IC and AY-IB phytoplasmas in 2002 and 2003 (Table 5). AY-IC phytoplasma was isolated from strawberry (5), and AYIB phytoplasma was isolated from Rehmannia glutinosa (19). Both were maintained in the greenhouse as controls. The

Table 5. Graft and dodder transmission of phytoplasmas from periwinkle to currant seedlings

\begin{tabular}{lclccc}
\hline Cultivar & Phytoplasma $^{\mathbf{a}}$ & Transmission & No. of plants & Symptoms $^{\mathbf{b}}$ & $\begin{array}{c}\text { PCR }^{\mathbf{c}} \\
\text { phytoplasma }^{-}\end{array}$ \\
\hline Jonkheer & AY-IC & Bottle grafting & 10 & $\mathrm{nf}$ & 3 \\
van Tets & & Bark grafting & 9 & $\mathrm{nf}$ & 0 \\
& & Dodder & 4 & $\mathrm{HF}$ & 2 \\
& AY-IB & Approach grafting & 6 & $\mathrm{nf}$ & 1 \\
& & Dodder & 1 & $\mathrm{HF}$ & 1 \\
Baldwin & AY-IC & Dodder & 2 & $\mathrm{HF}$ & 0 \\
& AY-IB & Approach grafting & 3 & $\mathrm{HF}$ & 0 \\
& & Dodder & 1 & $\mathrm{HF}$ & 0
\end{tabular}

a AY-IC, aster yellows phytoplasma (subgroup 16SrI-C); AY-IB, aster yellows phytoplasma (subgroup 16SrI-B).

${ }^{\mathrm{b}}$ nf, no flowers; HF, healthy flowers.

${ }^{c} \mathrm{PCR}$, polymerase chain reaction.

Table 3. Symptoms and the presence of Blackcurrant reversion virus and phytoplasma in currant seedlings after graft transmission of full blossom disease to seedlings ${ }^{\mathrm{a}}$

\begin{tabular}{|c|c|c|c|c|c|c|c|c|c|}
\hline \multirow[b]{2}{*}{ Cultivar } & \multirow[b]{2}{*}{ Plant } & \multirow[b]{2}{*}{ Scion } & \multicolumn{5}{|c|}{ Symptoms $^{b}$} & \multicolumn{2}{|c|}{$\mathbf{P C R}^{\mathrm{c}}$} \\
\hline & & & 2004 & 2005 & 2006 & 2007 & 2008 & BRV & Phytoplasma \\
\hline \multirow{15}{*}{ Jonkheer van Tets } & 1 & Rožmitál & $\mathrm{nf}$ & $\mathrm{nf}$ & $\mathrm{nf}$ & $\mathrm{nf}$ & $\mathrm{nf}$ & $\mathrm{P}$ & AY-IC \\
\hline & 2 & Rožmitál & $\mathrm{nf}$ & $\mathrm{nf}$ & $\mathrm{HF}$ & $\mathrm{nf}$ & $\mathrm{nf}$ & $\mathrm{P}$ & $\mathrm{N}$ \\
\hline & 3 & Rožmitál & $\mathrm{nf}$ & $\mathrm{nf}$ & $\mathrm{HF}$ & $\mathrm{nf}$ & $\mathrm{nf}$ & $\mathrm{P}$ & $\mathrm{N}$ \\
\hline & 43 & Jonkheer van Tets & $\mathrm{nf}$ & $\mathrm{nf}$ & $\mathrm{nf}$ & $\mathrm{nf}$ & FBD & Ps & $\mathrm{N}$ \\
\hline & 44 & Jonkheer van Tets & $\mathrm{nf}$ & $\mathrm{nf}$ & $\mathrm{nf}$ & $\mathrm{nf}$ & FBD & $\mathrm{P}$ & $\mathrm{N}$ \\
\hline & 45 & Jonkheer van Tets & $\mathrm{nf}$ & $\mathrm{nf}$ & $\mathrm{nf}$ & $\mathrm{nf}$ & FBD & $\mathrm{P}$ & $\mathrm{N}$ \\
\hline & 46 & Vitan & $\mathrm{nf}$ & $\mathrm{nf}$ & $\mathrm{HF}$ & $\mathrm{nf}$ & $\mathrm{nf}$ & Ps & $\mathrm{N}$ \\
\hline & 47 & Vitan & $\mathrm{nf}$ & $\mathrm{nf}$ & $\mathrm{nf}$ & $\mathrm{nf}$ & $\mathrm{HF}$ & $\mathrm{P}$ & $\mathrm{N}$ \\
\hline & 48 & Vitan & $\mathrm{nf}$ & $\mathrm{nf}$ & $\mathrm{nf}$ & nf & $\mathrm{nf}$ & Ps & $\mathrm{N}$ \\
\hline & 49 & Vitan & $\mathrm{nf}$ & $\mathrm{nf}$ & $\mathrm{nf}$ & $\mathrm{nf}$ & $\mathrm{HF}$ & $\mathrm{P}$ & $\mathrm{N}$ \\
\hline & 50 & Jonkheer van Tets & $\mathrm{nf}$ & $\mathrm{nf}$ & $\mathrm{nf}$ & $\mathrm{nf}$ & FBD & $\mathrm{P}$ & $\mathrm{N}$ \\
\hline & 51 & Vitan & $\mathrm{nf}$ & $\mathrm{nf}$ & $\mathrm{nf}$ & $\mathrm{nf}$ & $\mathrm{HF}$ & $\mathrm{P}$ & $\mathrm{N}$ \\
\hline & 52 & Jonkheer van Tets & $\mathrm{nf}$ & $\mathrm{nf}$ & $\mathrm{nf}$ & $\mathrm{nf}$ & FBD & $\mathrm{P}$ & $\mathrm{N}$ \\
\hline & 53 & Jonkheer van Tets & $\mathrm{nf}$ & $\mathrm{nf}$ & $\mathrm{nf}$ & nf & $\mathrm{nf}$ & $\mathrm{P}$ & $\mathrm{N}$ \\
\hline & 54 & Jonkheer van Tets & $\mathrm{nf}$ & $\mathrm{nf}$ & $\mathrm{nf}$ & $\mathrm{nf}$ & FBD & $\mathrm{P}$ & $\mathrm{N}$ \\
\hline \multirow[t]{3}{*}{ Baldwin } & 6 & Vitan K8 & $\mathrm{nf}$ & $\mathrm{HF}$ & $\mathrm{nf}$ & $\mathrm{HF}$ & $\mathrm{HF}$ & $\mathrm{P}$ & $\mathrm{N}$ \\
\hline & 17 & Vitan & $\mathrm{nf}$ & $\mathrm{HF}$ & $\mathrm{nf}$ & $\mathrm{nf}$ & $\mathrm{HF}$ & $\mathrm{N}$ & AY-IC \\
\hline & 35 & Vitan K3 & $\mathrm{nf}$ & $\mathrm{HF}$ & $\mathrm{nf}$ & $\mathrm{nf}$ & $\mathrm{nf}$ & $\mathrm{P}$ & $\mathrm{N}$ \\
\hline
\end{tabular}

a Grafting was done in 2002.

${ }^{\mathrm{b}} \mathrm{nf}$, no flowers; HF, healthy flowers; FBD, full blossom disease.

${ }^{\mathrm{c}}$ PCR, polymerase chain reaction; BRV, Blackcurrant reversion virus; P, positive; N, negative; AY-IC, aster yellows phytoplasma (subgroup 16SrI-C); Ps, positive, sequenced.

Table 4. Dodder transmission of phytoplasma from currants to periwinkle

\begin{tabular}{|c|c|c|c|c|c|c|}
\hline \multirow[b]{2}{*}{ Plant } & \multirow[b]{2}{*}{ Phytoplasma $^{\mathbf{a}}$} & \multirow{2}{*}{$\begin{array}{l}\text { Phytoplasma } \\
\text { AC number }\end{array}$} & \multirow{2}{*}{$\begin{array}{c}\text { BRV }^{\mathbf{b}} \\
\text { AC number }\end{array}$} & \multicolumn{3}{|c|}{ Periwinkle plants } \\
\hline & & & & Dodder bridged & PCR $^{c}$ positive & Symptoms $^{d}$ \\
\hline Rožmitál & AY-IC & AY 669063 & DQ 750974 & 4 & 2 & GP \\
\hline Vitan K2 & AY-IC & AY 966889 & DQ 450977 & 3 & 0 & $\mathrm{HF}$ \\
\hline Vitan K3 & AP & AY 669060 & DQ 450976 & 2 & 0 & $\mathrm{HF}$ \\
\hline Vitan K7 & $\mathrm{AP}$ & AY 669061 & $\mathrm{Ps}^{\mathrm{e}}$ & 1 & 0 & $\mathrm{HF}$ \\
\hline Vitan K8 & AP & AY 669062 & DQ 450975 & 21 & 0 & $\mathrm{HF}$ \\
\hline Blanka K5 & AY-IC & AY 669064 & DQ 450987 & 6 & 0 & $\mathrm{HF}$ \\
\hline Viola 5 & AY-IB & EU927367f & DQ 450978 & 9 & 0 & $\mathrm{HF}$ \\
\hline Viola 52 & AY-IB & EU927367f & $\mathrm{Ps}^{\mathrm{e}}$ & 19 & 0 & $\mathrm{HF}$ \\
\hline
\end{tabular}

a AY-IC, aster yellows phytoplasma (subgroup 16SrI-C); AP, apple proliferation phytoplasma; AY-IB, aster yellows phytoplasma (subgroup 16SrI-B).

${ }^{\mathrm{b}} \mathrm{BRV}$, Blackcurrant reversion virus.

${ }^{c}$ PCR, polymerase chain reaction.

${ }^{\mathrm{d}} \mathrm{GP}$, green petal; HF, healthy flowers.

e Ps, positive, sequence not submitted to GenBank.

${ }^{\mathrm{f}}$ Phytoplasma sequences were identical. 
periwinkle scions in the bottle-grafted plants were kept in water for 6 months and covered with a plastic bag for 2 months. Periwinkle scions in approach and bark grafts were taped in place and maintained for 3 months. Dodder transmission experiments were also conducted from periwinkle to currant with these phytoplasma isolates. In subsequent years (2004 to 2008), symptoms were assessed and the presence of phytoplasma was tested by PCR and sequencing.

Phytoplasma detection. Total DNA was extracted from $3 \mathrm{~g}$ of the following tissues: the midribs and leaf petioles of symptomatic currant branches and controls, and young shoots with leaves of both healthy control and infected periwinkle plants (9). The nucleic acid pellet was resuspended in $50 \mu \mathrm{l}$ of TE buffer $(10 \mathrm{mM}$ Tris- $\mathrm{HCl}, 1$ mM EDTA) at a final concentration of 20 ng $\mu l^{-1}$ (9). DNA extracts were used as template in the PCR reactions to amplify a portion of the 16S RNA (rRNA) gene. The universal primer pair R16P1 (3) and $\mathrm{R} 16 \mathrm{P} 7$ (27) was used in the first (direct) amplification, followed by nested-PCR using primer pair R16F1/B6 (18). The internal primers R16F2/R2 (6) were used in the third amplification (double nestedPCR) to amplify the product for sequencing. The R16F2/R2 primer pair amplifies a DNA fragment of approximately $1,200 \mathrm{bp}$ localized between 152 and 1,397 bp from the $16 \mathrm{~S}$ rRNA gene region in the phytoplasma DNA. A total volume of $25 \mu \mathrm{l}$ contained $1 \mu \mathrm{l}$ of DNA, $200 \mu \mathrm{mol}$ liter $^{-1}$ dNTPs, $0.5 \mu \mathrm{l}$ of each primer (from $20 \mathrm{pmol}^{-1} \mathrm{l}^{-1}$ stock solution), $75 \mathrm{mM}$ Tris- $\mathrm{HCl} \mathrm{pH} \mathrm{8.8,} 20$ $\mathrm{mM}\left(\mathrm{NH}_{4}\right)_{2} \mathrm{SO}_{4}, 0.01 \%$ Tween $20,2.5 \mathrm{mM}$ $\mathrm{MgCl}_{2}, 2.5 \mathrm{U}$ of $\mathrm{Taq}$ purple DNA polymerase, and stabilizers (Taq-Purple DNA Polymerase PCR Master Mix with $\mathrm{MgCl}_{2}$, Top-Bio Ltd., Prague, Czech Republic). Amplification consisted of 35 cycles and was conducted using an MJ Research Thermocycler (Watertown, MA, USA). The following parameters were used: initial denaturation at $94^{\circ} \mathrm{C}$ for $2 \mathrm{~min}, 35$ cycles of denaturation at $94^{\circ} \mathrm{C}$ for $1 \mathrm{~min}$, annealing at $50^{\circ} \mathrm{C}$ for $2 \mathrm{~min}$, and extension at $72^{\circ} \mathrm{C}$ for $3 \mathrm{~min}$. The final step was performed at $72^{\circ} \mathrm{C}$ for $10 \mathrm{~min}$ (10). Six microliters of each PCR product was analyzed by electrophoresis in a $1 \%$ agarose gel, followed by SYBR Green I staining and visualization of DNA bands using a UV transilluminator.

Restriction fragment length polymorphism (RFLP) analysis. The R16F2/R2 DNA fragments amplified from phytoplasma-positive currant bushes were digested with $2.5 \mathrm{U}$ of AluI, HhaI, KpnI, $M s e I$, and $R s a \mathrm{I}$ restriction endonucleases for at least $16 \mathrm{~h}$ according to the instructions of the manufacturer (MBI Fermentas). The restriction fragments were separated by electrophoresis in an $8 \%$ polyacrylamide gel in $1 \times$ TBE buffer and stained with ethidium bromide.
Phytoplasma sequencing. The PCR products from infected shrubs generated by amplification with primers $\mathrm{R} 16 \mathrm{~F} 2 / \mathrm{R} 2$ (6) were sequenced from both directions using a BIG DYE sequencing terminator kit (PE Biosystems, Warrington, UK). Sequencing was performed with an ABI PRISM 310 sequencer (PE Applied Biosystems, Foster City, CA, USA). The nucleic acid sequences of PCR products obtained from the selected samples were analyzed by pair-wise comparison with the phytoplasma sequences available in GenBank using the BLAST algorithm at www.ncbi.nlm.nih.gov/BLAST.

Electron microscopy. Flower, raceme, midrib, and sprout samples from the currant plants were examined. Tissue pieces (approximately $2 \times 2 \mathrm{~mm}$ ) were fixed in $0.1 \mathrm{M}$ potassium phosphate buffer $\mathrm{pH} 7.3,5 \%$ glutaraldehyde, and $4 \%$ sucrose for over 24 $\mathrm{h}$ at $4^{\circ} \mathrm{C}$ under a mild vacuum. The samples were postfixed in $1 \%$ osmium tetraoxide, dehydrated in ethanol, and embedded in Durcupan resin (Fluka). Thin sections were double-stained with uranyl acetate in $70 \%$ ethanol and lead citrate, and then examined with a Jeol $100 \mathrm{MB}$ electron microscope (JEOL Inc., Peabody, MA, USA).

Amplification of BRV nucleic acid and virus detection. RNA was isolated from about $100 \mathrm{mg}$ of fresh leaf tissue using the RNeasy Plant Mini Protocol for isolation of total RNA from plant cells and tissues (QIAGEN GmbH, Germany), and the RNA extracts were used for standard RT-PCR (AccessQuick RT-PCR System, Promega Corporation, USA). To amplify the $3^{\prime}-\mathrm{NTR}$ of RNA-2 in BRV, primers P5/P6 (PCR product of $481 \mathrm{nt}$ ) (13) and P16/BCP11 (PCR product of $786 \mathrm{nt}$ ) (11) were used. Each $50-\mu l$ reverse transcription reaction contained 50 pmol of each primer, $1 \mu \mathrm{l}$ of extracted RNA, and $5 \mathrm{U}$ of AMV reverse transcriptase. The cDNA was synthesized for $45 \mathrm{~min}$ at $45^{\circ} \mathrm{C}$, and the reaction was stopped with a 2-min denaturation at $95^{\circ} \mathrm{C}$. The amplification comprised 40 cycles of denaturation at $95^{\circ} \mathrm{C}$ for $30 \mathrm{~s}$, annealing at $60^{\circ} \mathrm{C} \quad(\mathrm{P} 5 / \mathrm{P} 6), \quad 51^{\circ} \mathrm{C}$ (P16R/BCP11), or $49^{\circ} \mathrm{C}(\mathrm{P} 1 / \mathrm{P} 2)$ for $1 \mathrm{~min}$, extension at $68^{\circ} \mathrm{C}$ for $2 \mathrm{~min}$, and a final step at $68^{\circ} \mathrm{C}$ for $7 \mathrm{~min}$, and was conducted in an MJ Research thermocycler (Watertown, MA, USA). The presence of BRV was detected using the RT-PCR method previously described (11) and primers P1/P2 (PCR product of $215 \mathrm{nt}$ ).

Aliquots $(20 \mu \mathrm{l})$ of the PCR products were analyzed by electrophoresis in a $2 \%$ agarose gel in $1 \times$ Tris-acetate-EDTA buffer (40 mM Tris-acetate and $1 \mathrm{mM}$ EDTA, $\mathrm{pH}$ 8.0) stained with ethidium bromide and viewed under UV light. The negative (healthy) control was obtained from a virus-indexed nuclear stock plant of black currant Öjebyn. The positive control for BRV was a back-inoculated black currant cv. Mortti. Both controls originated from MTT Agrifood Research Finland.
Sequence analysis. PCR products of 215 nt generated by amplification with primers P1/P2 (position 6185-6400), 481 nt generated by amplification with primers P5/P6 (nt position 5655-6135, numbering according to accession number AF020051), and 786 nt generated with primers P16/BCP11 (nt position 4951-5737) were obtained from each sample and sequenced directly using a BigDye sequencing terminator kit (PE Biosystems, Warrington, UK). Sequencing was performed in both directions using an ABI PRISM 310 sequencer (PE Applied Biosystems, Foster City, CA, USA). The sequences were aligned using ClustalW, and phylogenetic analysis was performed using the DNADIST and NEIGHBOR programs in the PHYLIP package (4).

\section{RESULTS}

Graft transmission of FBD to currant cultivars. To elucidate the etiology of FBD, we conducted experiments with bark grafts (scions) from FBD naturally infected shrubs onto healthy rootstocks. This experiment eliminates the possibility that FBD is just a physiological disorder and facilitates phytoplasma or virus identification after their transmission to an indicator host plant, as both phytoplasma and viruses are graft transmissible. The results are summarized in Table 1. For clarity and to save space, Table 2 shows the detailed results of only those plants that revealed symptoms or were BRV- or phytoplasmapositive in 2001 to 2008 . The first symptoms appeared in 2001, 2 years after grafting. Symptoms did not appear every year. This is in accordance with our observation of the irregular appearance of FBD symptoms in the same plant during different years, in plants both naturally infected in the field as well as potted in a greenhouse (29). The red currants Jonkheer van Tets (Fig. 1) and Vitan (Fig. 2) and white currant Blanka showed symptoms of FBD. One plant of Rondom revealed symptoms in 2001, but was symptomless during the following years, with neither BRV nor phytoplasma detected. Only one plant among the Jonkheer van Tets and Blanka was found to be infected with both BRV and phytoplasma (Table 2), although 7 and 13 plants were symptomatic, respectively. The graft-transmitted phytoplasmas were identified as AY-IC and AY-IB. No differences in symptoms were observed in the two plants infected with both BRV and phytoplasma and those infected with BRV only. With the exception of Rondom, BRV was detected in all symptomatic plants.

The black currant Viola exhibited symptoms of the R-form of BCRD (Fig. 3). Öjebyn remained symptomless, although the presence of BRV was confirmed by sequencing of the PCR product. We detected BRV in all symptomatic Viola plants, but only two plants were found to be simultaneously infected with AY-IB phytoplasma. 
Analogous to the red and white currants, we did not observe any differences in symptoms between Viola plants infected with BRV only and those infected with both BRV and phytoplasma. Based on ELISA, all plants were found to be free of ApMV, ArMV, ToRSV, CLRV, AMV, TSV, SLRV, TBRV, RpRSV, RBDV, and CMV, viruses that may occur in currants $(2,7)$.

Graft transmission of FBD to seedlings of the Jonkheer van Tets and Baldwin

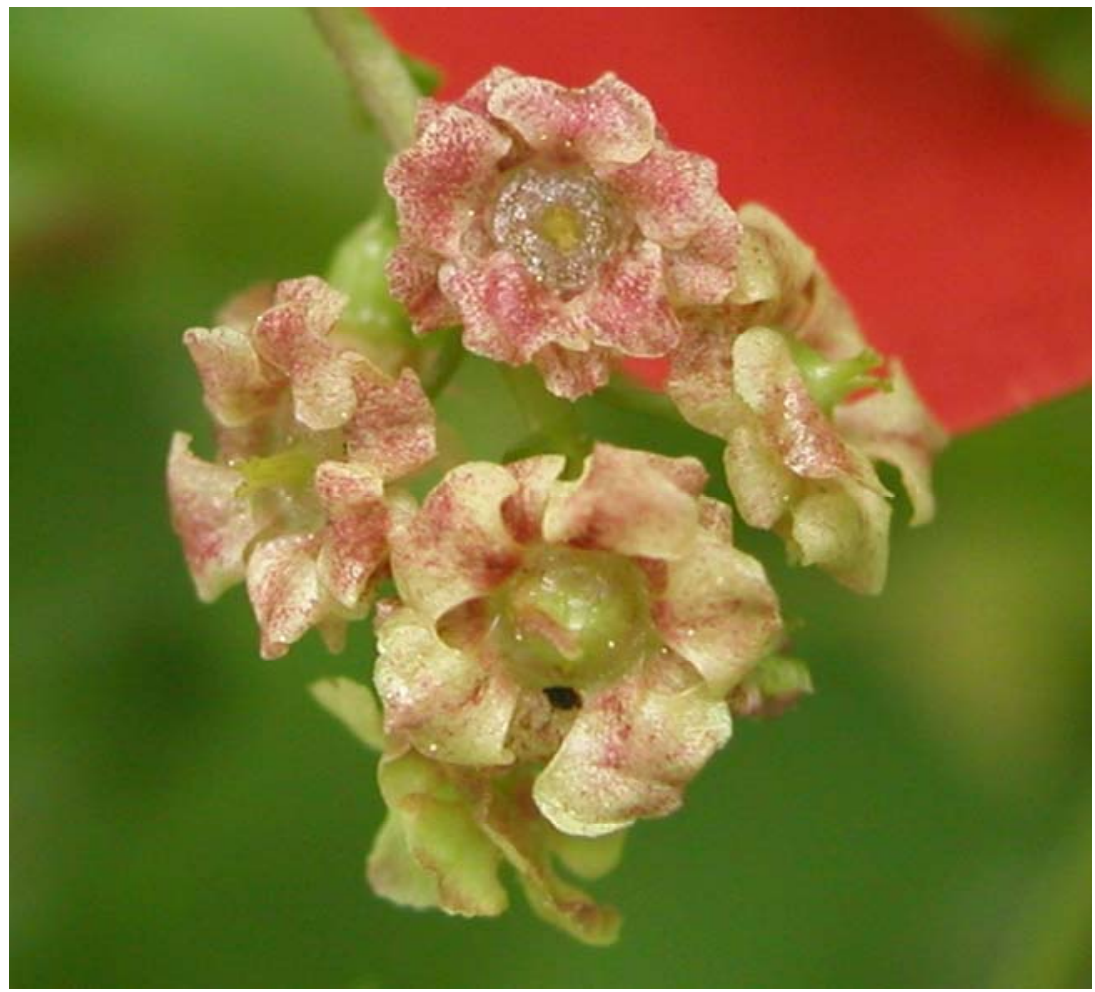

Fig. 1. Detailed flower malformation in a full blossom disease-affected red currant 'Jonkheer van Tets'.

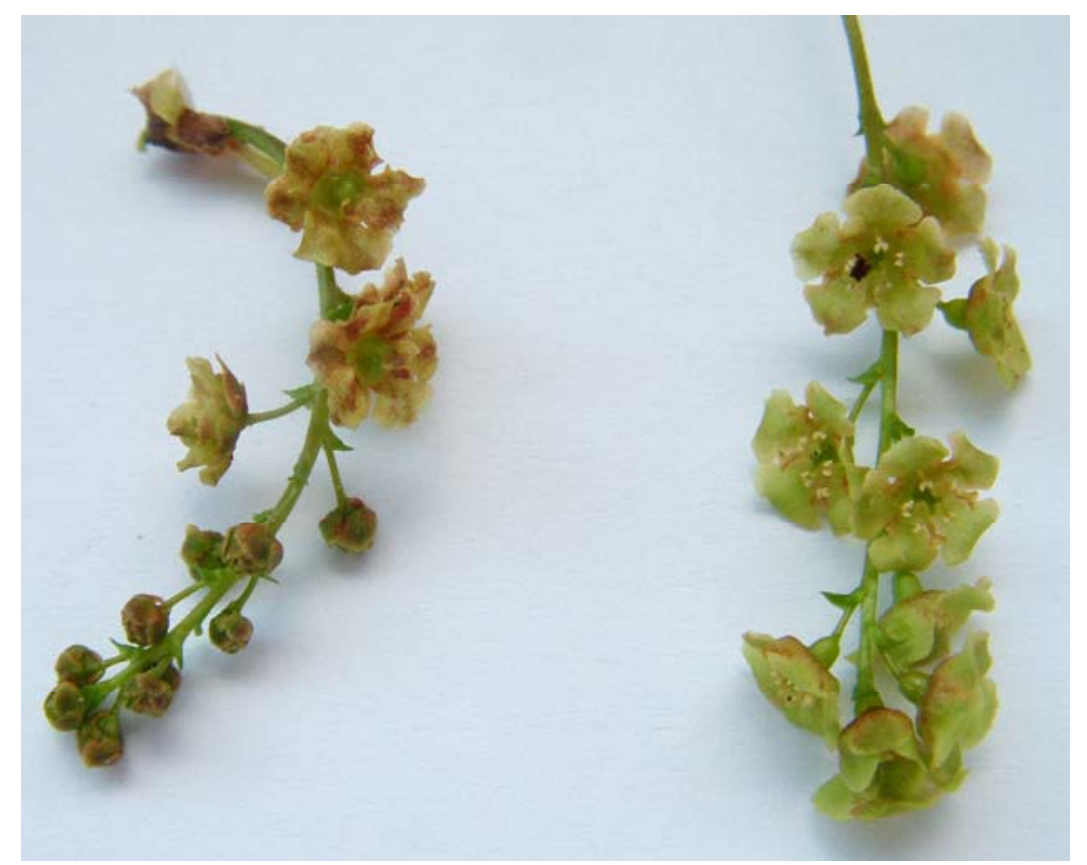

Fig. 2. Full blossom disease-affected flower raceme of red currant 'Vitan' in comparison with healthy raceme (right) currants. The results are summarized in the lower part of Table 1; the details of symptomatic and pathogen-positive plants are displayed in Table 3. The first symptoms were observed in 2008. Of 15 grafted Jonkheer van Tets plants, all tested positive for the presence of BRV by RT-PCR, but only five displayed symptoms of FBD 5 years after grafting. One plant that was simultaneously infected with phytoplasma AY-IC, as determined by PCR, did not exhibit any

symptoms. Of 41 FDB-grafted Baldwin plants, two were BRV positive and only one was phytoplasma (AY-IC) positive; however, none of these has developed any symptoms thus far. The major problem encountered in this experiment was that plants raised from seed bloomed very poorly after several years of cultivation.

Dodder transmission of phytoplasmas from currants to periwinkle and their back-transmission to red and black currants. We successfully transmitted AY-IC phytoplasma from the FBD-affected red currant Rožmitál to periwinkle (Catharanthus roseus L.) by dodder (Table 4). In two periwinkle plants that were PCR-positive for phytoplasma, we observed symptoms of green and yellow petals. The phytoplasma sequences found in Rožmitál currant and periwinkle plants were identical. Phytoplasma bodies were observed in the flower stalks and leaf petioles of infected periwinkles by electron microscopy. Periwinkle plants tested negative by RT-PCR for the presence of BRV. Attempts to isolate phytoplasma from the other seven currants (red, white, black) were unsuccessful. In total, the phytoplasma transmission rate was very low, as only two of 65 dodder-bridged periwinkle plants were infected.

Experiments examining the backtransmission of AY-IC phytoplasma (isolated from Rožmitál) by dodder-bridge from periwinkle to the seedlings of Jonkheer van Tets and Baldwin were unsuccessful. Neither five Jonkheer van Tets nor two Baldwin plants were infected. No symptoms were observed in 2003 to 2008 , and PCR tests in 2004, 2005, and 2006 were negative for phytoplasma.

Dodder and graft transmission of phytoplasmas from periwinkle to Jonkheer van Tets and Baldwin indicator plants. Due to poor results for the transfer of phytoplasmas from FBD-affected currants to periwinkle and the difficulty associated with propagation of periwinkle plants infected with the AY-IC phytoplasma isolated from Rožmitál, we conducted bottle-, bark-, and approach-graft and dodder transmission experiments with phytoplasma AY-IC maintained in our greenhouse as controls. AY-IC phytoplasma control maintained in periwinkle was successfully bottle-grafted and dodder-transmitted to seedlings of the red currant Jonkheer van Tets (Table 5). Similarly, AY-IB phytoplasma was transmitted by approach-grafting and dodder, as confirmed by RFLP analysis and sequencing of the PCR products. This is the first evidence that phytoplasma can infect red currants in the absence of synergism with BRV. We observed no symptoms over the course of 6 years, as the plants developed healthy flowers or were not flowering. Attempts to transmit both phytoplasmas to the Baldwin seedlings were unsuccessful. 


\section{DISCUSSION}

When we first observed FBD symptoms in red and white currants identical to those described by Rakús (23) in the field in 1998, our intention was to identify the causal phytoplasma(s) by molecular methods, examine phloem cells of symptomatic plants by electron microscopy, and test their transmission by grafting.

The only evidence of phytoplasma as a causal agent of FBD in symptomatic currants in the literature (25) is provided by four convincing electron micrographs. They display numerous pleomorphic bodies in the phloem of the green racemes of symptomatic sprouts of the red currant Houghton Castle. During our study, we examined a total of 75 samples of flowers, racemes, and leaf midribs representing 54 different fully blossomed FBD plants of various cultivars and locations. We found only a few phytoplasma bodies in the phloem cells of two plants-Rožmitál (16) and Vitan K7 (Table 5) (30). Houghton Castle may have been very sensitive to phytoplasma because FBD was not observed among 41 cultivars at the research station in Bojnice in 1973 (24).

The results in Table 1 show that the transmission of phytoplasma, which was verified and identified by RFLP analysis and sequencing, was rarely successful. Transmission of phytoplasma was not

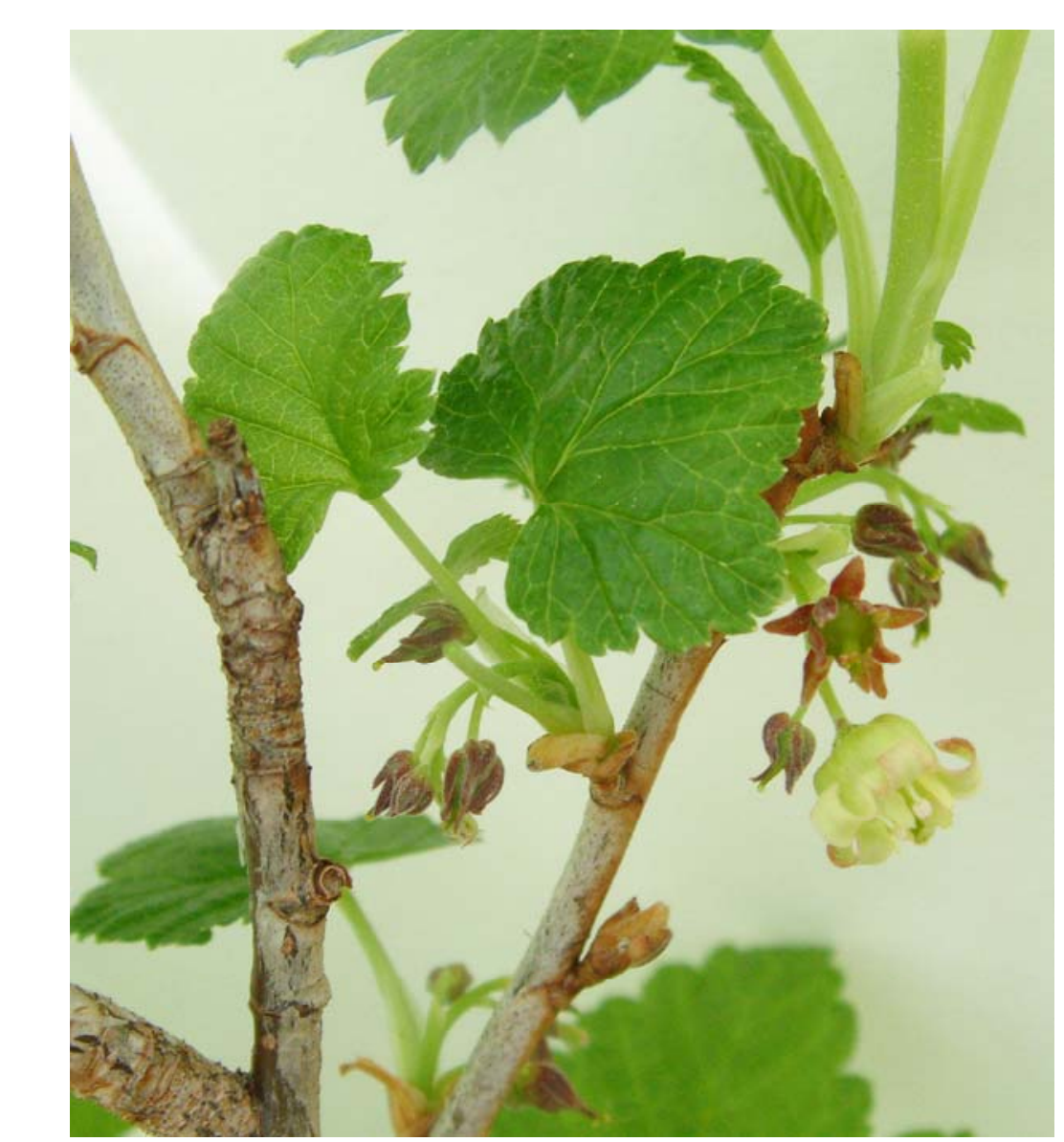

Fig. 3. Symptoms of the R-form of blackcurrant reversion disease in black currant 'Viola' grafted with full blossom disease. Severely malformed, dark, sterile flowers contrast with the one healthy flower

exhibiting fully developed stamens.

necessary for symptom appearance, indicating that phytoplasma is not the causal agent of FBD. Successful graft transmission of FBD was conducted (24) by patchand bark-grafting between symptomatic and 1-year-old seedlings of Houghton Castle. During the first and second years, the transmission rate (evaluated according to FBD symptoms) was 16.66 and $100 \%$, respectively. Van der Meer (32) mentioned that graft-inoculated red currant 'Heinemann's Rote Spätlese' and black currant Baldwin plants became infected latently; however, there are no data in the literature indicating how this latent infection was determined. The results (26) correspond to our data obtained for BRV transmission, in particular to those obtained for the Jonkheer van Tets seedlings.

In general, phytoplasma detection in shrubs and woody hosts by PCR is very difficult (28). Specifically, nucleic acid isolation from phytoplasma in the phloem tissue, followed by its amplification with universal $16 \mathrm{~S}$ rRNA primers, may provide false positive results. In initial attempts to identify phytoplasmas in FBD-infected currants, a high level of inconsistency in results between symptomatic plants assessed by PCR-positive amplification (17) and RFLP identification of phytoplasmas was observed (16). To overcome problems with nonspe- cific amplification, we routinely sequenced all phytoplasma-positive PCR samples used in our transmission experiments.

The identification of BRV as a causal agent of BCRD $(8,12)$ led to testing for the presence of BRV in FBD currants, which was demonstrated in 2001 (21). Low virus titers and erratic distribution in FBDaffected plants caused the molecular detection of BRV to be difficult. Improvements in sampling, isolation, primer design, and RTPCR protocol optimization according to previous studies $(11,13)$ resulted in greater reproducibility of the results and a good correlation between the FBD symptoms and BRV RT-PCR-positive results. Our FBD graft transmission experiment (Tables 1 and 2) showed higher transmission rates for BRV than for phytoplasma, significantly correlating BRV infection with FBD symptoms. The higher graft transmission rate of BRV to red and white currant cultivars may be the result of better compatibility between rootstock and scions originating from red and white currants compared to scions from Ribes rubrum grafted on $R$. nigrum. This is particularly evident based on the transmission experiments with currant seedlings. Nevertheless, we observed significant differences in BRV transmission between the red cultivars Rondom and Vitan. Similarly, Öjebyn was more resistant to BRV graft transmission than Viola. With respect to the results of repeated testing during several years, BRV detection was very reliable, and was further confirmed by sequencing the PCR products obtained from selected plants.

The cultivars used in our graft experiments originated from commercially certified stock that was not previously tested for BRV and phytoplasma. As a result, we performed additional experiments with seedlings of red currant from Jonkheer van Tets and black currant Baldwin test plants raised from seeds. Test plants were cultivated in an insect-free greenhouse to avoid possible contamination with BRV and phytoplasma, which are not seed-transmissible. Both cultivars are recommended by EPPO certification schemes for Ribes (1). Table 1 and Table 3 show that the results were similar to those obtained with commercial seedlings, but revealed problems associated with late and poor blooming of currants raised from seed. The most significant result from the FBD graft transmission experiments was that there was no difference in symptoms observed between plants infected with BRV only compared to those infected with both BRV and phytoplasma.

In contrast to BCRD etiology (12), there was no previous experimental evidence regarding whether phytoplasma infection itself may cause any disease symptoms in currants. Detection of FBD symptomatic plants in the field infected with only phytoplasma would be extremely difficult, and large-scale testing would be expensive.

Therefore, we attempted to partially fulfill Koch's postulates - to "isolate" phyto- 
plasma from currants by dodder-bridge to periwinkle (a test plant for phytoplasma), which is not a host for BRV. For this experiment, we carefully selected shrubs infected with both phytoplasma and BRV, as identified by PCR and RT-PCR, RFLP analysis, and sequencing (Table 4). Despite tremendous efforts, the results were rather poor. Only AY-IC phytoplasma was successfully transmitted from Rožmitál to periwinkle and induced symptoms of green petals and yellowing from Rožmitál and induced symptoms of green petals and yellowing in periwinkle. Unfortunately, the infected periwinkle died. Consequently, the back-transmission of phytoplasma to the seedlings of Jonkheer van Tets and Baldwin was not successful.

Thus, we performed transmission experiments with AY-IC and AY-IB phytoplasma controls isolated from strawberry (Table 5) and Rehmannia that resulted in positive bottle- and approach-graft, and dodder transmission. However, no symptoms of phytoplasma infection were observed in currants.

Based on our results, we conclude that although phytoplasma may be present in mixed infections together with BRV in Ribes plants with symptoms of FBD, the symptoms are induced by the virus rather than by phytoplasma, which was originally described as the causal agent of FBD. This conclusion is further supported by our previous finding of phytoplasma in the black currant 'Karlštejnský Dlouhohrozen' with symptoms of the R-form of BCRD. Neighboring plants on a plantation exhibited identical symptoms, although some of them were infected only with BRV, while others were infected with both BRV and phytoplasma (20).

The fact that FBD transmission to the black currant Viola (Table 2) resulted in symptoms of the R-form of BCRD and that there were no differences in symptoms between plants infected only with BRV and those infected with BRV and phytoplasma suggest that FBD in red and white currants and the R-form of BCRD in black currants are due to the common causal agent BRV. This conclusion is supported by the fact that there is no significant sequence diversity among BRV isolates associated with either FBD in red and white currants or with the R-form of BCRD in black currants (22).

To eliminate FBD or BCRD from the currant propagation stock, we recommend observing the symptoms at the time of blooming, testing symptomless plants by RT-PCR and PCR for the presence of BRV and phytoplasma, respectively, and finally, verifying by sequencing the PCR products.

\section{ACKNOWLEDGMENTS}

This work was supported by grants 1P05OC051 from the Ministry of Education and AV0Z50510513 from the Academy of Sciences of the Czech Republic and COST 863 Action. We thank A. Bertaccini, University of Bologna, Italy, for recommendations regarding phytoplasma detection, M. Barba, ISPAVE, Rome, Italy, for dodder seeds, A. Lemmetty, MTT, Jokioinen, Finland, and A. T. Jones, SCRI, Scotland for recommendations regarding BRV detection and †Ing. R. Karešová, RBIP, Holovousy, Czech Republic for the Jonkheer van Tets and Baldwin seeds.

\section{LITERATURE CITED}

1. Anonymous. 2008. Certification scheme for Ribes. Bull. OEPP/EPPO 38:14-18.

2. Converse, H. R. 1987. Virus diseases of small fruits. Pages 127-166 in: U.S. Dep. Agric. Handb. No. 631.

3. Deng, S., and Hiruki, C. 1991. Genetic relatedness between two nonculturable mycoplasmalike organisms revealed by nucleic acid hybridization and polymerase chain reaction. Phytopathology 81:1475-1479.

4. Felsenstein, J. 1989. PHYLIP (Phylogeny inference package) version 3.6. Distributed by the author, Department of Genetics, University of Washington, Seattle.

5. Fránová-Honetšlegrová, J., Vibio, M., and Bertaccini, A. 1996. Electron microscopy and molecular identification of phytoplasmas associated with strawberry green petals in the Czech Republic. Eur. J. Plant Pathol. 102:831-835.

6. Gundersen, D. E., Lee, I. M., Schaff, D. A., Harrison, N. A., Chang, C. J., Davis, R. E., and Kingsbury, D. T. 1996. Genomic diversity and differentiation among phytoplasma strains in 16S rRNA groups I (aster yellows and related phytoplasmas) and III (X-disease and related phytoplasmas). Int. J. Syst. Bacteriol. 46:64-75.

7. Janečková, M., and Svobodová, L. 1995. Determination of five viruses in plants of black, red and white currant by ELISA. Zahradnictví $22: 47-51$

8. Jones, A. T. 2000. Black currant reversion disease - the probable causal agent, Eriophyid mite vectors, epidemiology and prospects for control. Virus Res. 71:17-84.

9. Lee, I.-M., Davis, R. E., and Hiruki, C. 1991. Genetic relatedness among clover proliferation mycoplasma-like organisms (MLOs) and other MLOs investigated by nucleic acid hybridization and restriction length polymorphism analyses. Appl. Environ. Microbiol. 57:3565-3569.

10. Lee, I.-M., Hammond, R. W., Davis, R. E., and Gundersen, D. E. 1993. Universal amplification and analysis of pathogen 16S rDNA for classification and identification of mycoplasmalike organisms. Phytopathology 83:834-842.

11. Lemmetty, A., Latvala-Kilby, S., and Lehto, K. 2001. Comparison of different isolates of Blackcurrant reversion virus. Acta Hortic. 551:45-49.

12. Lemmetty, A., and Lehto, K. 1999. Successful back-inoculation confirms the role of black currant reversion associated virus as the causal agent of reversion disease. Eur. J. Plant Pathol. 105:297-301.

13. Lemmetty, A., Susi, P., Latvala, S., and Lehto, K. 1998. Detection of putative causal agent of blackcurrant reversion disease. Acta Hortic. 471:93-98.

14. Malinowski, T., Kuras, A., and Pluta, S. 2002. Comparison of the coat protein gene and non coding sequence region of RNA-2 of blackcurrant reversion virus isolated from black, red and white currant bushes. Conf. Eur. Found. Plant Pathol., 6th, Prague (poster presentation).

15. Navrátil, M., Přibylová, J., Válová, P., Fialová, R., Šafářová, D., Špak, J., Kubelková, D., Petrzik, K., and Karešová, R. 2007. Detection and identification of phytoplasmas in Ribes rubrum. Bull. Insectol. 60(2):135-136.

16. Navrátil, M., Přibylová, J., Válová, P., Fialová, R., Špak, J., Kubelková, D., and Karešová, R. 2004. Occurrence of phytoplasmas in red and white currants in the Czech Republic. Acta Hortic. 656:119-124.

17. Navrátil, M., Válová, P., Fialová, R., Špak, J., and Přibylová, J. 2001. First attempt on identification of phytoplasma associated with full blossom of red and white currant in the Czech republic. Acta Hortic. 551:51-54.

18. Padovan, A. C., Gibb, K. S., Bertaccini, A., Vibio, M., Bonfiglioli, R. E., Magarey, P. A and Sears, B. B. 1995. Molecular detection of the Australian grapevine yellows phytoplasma and comparison with a grapevine yellows phytoplasma from Emilia-Romagna in Italy. Aust. J. Grape Wine Res. 1:25-31.

19. Přibylová, J., Špak, J., Fránová, J., and Petrzik, K. 2001. Association of aster yellows subgroup 16SrI-B phytoplasmas with a disease of Reh mannia glutinosa var. purpurea. Plant Pathol. 50:652-657.

20. Přibylová, J., Špak, J., and Kubelková, D. 2002. Mixed infection of black currant (Ribes nigrum L.) plants with blackcurrant reversion associated virus and rhabdovirus-like particles with symptoms of black currant reversion disease. Acta Virol. 46:253-256.

21. Přibylová, J., Špak, J., Kubelková, D., and Lemmetty, A. 2004. The presence of Blackcurrant reversion virus in red and white currants with symptoms of full blossom disease. Acta Hortic. 656:131-136.

22. Přibylová, J., Špak, J., Petrzik, K., Kubelková D., and Špaková, V. 2008. Sequence comparison and transmission of the blackcurrant reversion virus isolates in black, red and white currants with black currant reversion disease and full blossom disease symptoms. Eur. J. Plant Pathol. 121:67-75.

23. Rakús, D. 1971. Nová Choroba Červených ribezlí. (A new disease of red currant.) Biologia (Bratislava) 26:355-358. (In Slovak.)

24. Rakús, D. 1973. Prenos "plnokvetosti" ríbezlí 'Houghton Castle' vrúblovaním. Ochrana Rostlin 9:143-144.

25. Rakús, D., Králík, O., and Brčák, J. 1974. Mycoplazma v Ribes houghtonianum Jancz. nakazené ,,plnokvetosti“ (Mycoplasma-like organism in Ribes houghtonianum Jancz, infected with a Yellows disease). Sbor. ÚVTI Ochrana Rostlin 10:307-309. (In Czech, abstr. in English.)

26. Rakús, D., and Maliarčiková,V. 1975. Štúdium škodlivosti choroby ,plnokvetost ${ }^{\circ}$ ribezle“ (currant full blossom) (Harmfulness of the currant full blossom.) Sborník ÚVTI - Zahradnictví 2:163-168. (In Slovak.)

27. Schneider, B., Seemüller, E., Smart, C. D., and Kirkpatrick, B. C. 1995. Phylogenetic classification of plant pathogenic mycoplasma-like organisms or phytoplasmas. Pages 369-380 in: Molecular and Diagnostic Procedures in Mycoplasmology. Vol. 1, Molecular Characterization. R. Razin and J. G. Tully, eds. Academic Press, San Diego, CA

28. Skrzeczkowski, L. J., Howell, W. E., and Eastwell, K. C. 2001. Bacterial sequences interfering in detection of phytoplasma by PCR using primers derived from the ribosomal RNA operon. Acta Hortic. 550:417-424.

29. Špak, J., Navrátil, M., Karešová, R., Přibylová, J., Válová, P., Kučerová, J., Kubelková, D., Fialová, R., and Špaková, V. 2006. Occurrence, symptom variation and yield loss caused by full blossom disease in red and white currants in the Czech Republic. Crop Prot. 25:446-453.

30. Špak, J., Navrátil, M., Přibylová, J., Válová, P. Fialová, R., Šafárová, D., Kubelková, D., Petrzik, K., and Špaková, V. 2007. Diagnosis of phytoplasmas associated with currants (Ribes sp.). Pages 387-397 in: Characterization, Diagnosis and Management of Phytoplasmas, chapter 18. N A. Harrison, G. P. Rao, and C. Marcone, eds. Studium Press LLC, Houston, TX, USA.

31. Susi, P. 2004. Black currant reversion virus, a mite transmitted nepovirus. Mol. Plant Pathol. 5:167-173.

32. Van der Meer, F. A. 1987. Full blossom of red currant. Pages 155-157 in: Virus diseases of small fruits. H. R. Converse, ed. U.S. Dep. Agric. Handb. No. 631 